\title{
ETOS KERJA PENGUSAHA MUSLIM (Studi Kasus pada Pengusaha Muslim Alumni UIN Walisongo Semarang)
}

\author{
Choirul Huda \\ UIN Walisongo Semarang \\ hudachoi99@gmail.com
}

\begin{abstract}
This study focused on the work ethos of Moeslim entrepreneurs who graduated from UIN $W$ alisongo Semarang. It is very interesting to study because of their profession as a businessmen and their educational background which based on Islamic sciences.

Through a qualitative descriptive approach, there are two issues to be answered, namely how the work ethos of Muslim entrepreneurs who graduated from UIN W alisongo Semarang in running a business and how relationships between work ethos of muslim entrepreneurs with their success in business?

Results of this study stated that Muslim entrepreneurs who graduated from UIN Walisongo Semarang have a high work ethic as capital in running and developing a business that was involved. Their work ethos is not only driven by economic motives, namely in order to meeth the economic needs alone, but it is also driven by social and religious motives. It correlates with the answer to the second issue, that, a bigh work ethich as been able to deliver the mon the success of the business that was involved, albeit with varying levels of success. It was determined by the type of business that is occupied and the time period to run the business. It also showed a good ability of the entrepreneur to manage and develop their business
\end{abstract}

Keywords: work ethic; entrepreneur; business.

\section{Pendahuluan}

Kemampuan pengusaha lokal dalam mengelola usaha perekonomian dan mampu bersaing di antara banyaknya kompetitor merupakan satu hal yang patut dihargai. Apalagi jika hal itu dikaitkan dengan pengusaha muslim di tengah-tengah kondisi umat Islam yang saat ini masih dirundung keterbelakangan, khususnya di bidang ekonomi. Hadirnya pengusaha muslim yang sukses (berhasil) akan sangat membantu dalam mendorong lahirnya 
pengusaha muslim lain untuk mengikuti jejaknya. Paling tidak mereka dapat menjadi panutan dalam berwirausaha (berdagang/berbisnis). Semangat mereka dalam berwirausaha sebagai perwujudan dari etos kerja yang tangguh itu perlu ditularkan kepada umat Islam lainnya.

Tidak banyaknya umat Islam yang terjun di dunia perdagangan/bisnis menimbulkan pertanyaan besar. Mengapa mereka kurang berminat dengan usaha perdagangan (bisnis)? Padahal jika kita merunut akar sejarah umat Islam, baik pada era kenabian dan para sahabat atau sesudahnya, tidak sedikit dari umat Islam saat itu yang terjun dan sukses menggeluti dunia perdagangan. Ajaran Islam sendiri mendorong umatnya untuk berkarya, bekerja keras, dan menghasilkan sebuah produktifitas dari tangannya sendiri, termasuk dengan menjadi pedagang. Rasul lebih menghargai orang yang bekerja dari pada peminta-minta (pemalas). ${ }^{1}$ Tidak tanggung-tanggung, Nabi Muhammad saw sendiri memberikan contoh dengan menjadi seorang pedagang. Lebih kurang 28 tahun lamanya Muhammad saw menjalankan usaha dagang tersebut. Wilayah perdagangannya meliputi Yaman, Syria, Busra, Irak, Yordania, Bahrain, dan kota-kota perdagangan di Jazirah Arab lainnya. Menurut satu riwayat, sebelum menikah, Muhammad saw menjadi manajer perdagangan Khadijah ke pusat perdagangan Habashah di Yaman. Muhammad juga 4 kali memimpin ekspedisi perdagangan untuk Khadijah ke Syria dan Jorash di Yordania. ${ }^{2}$

Pilihan Muhammad untuk menjadi pedagang tidak sekedar dipengaruhi oleh komunitas Arab saat itu yang mayoritas mata pencahariannya adalah pedagang, tetapi juga karena tumbuhnya kesadaran Muhammad tentang upaya kebangkitan atau kejayaaan dari keterpurukan yang bisa diraih melalui jalur perdagangan. Tidak heran jika di usia 12 tahun Muhammad kecil sudah berlatih berdagang ke Syiria, dan pada usia 25 tahun beliau sudah menjadi seorang manager bisnis yang sukses. Semua dilakukan secara sadar dengan pemahaman yang konkrit tentang manfaat perdagangan.

\footnotetext{
${ }^{1}$ Rasulullah saw bersabda, "Seandainya seseorang mencari kayu bakar dan dipikulkan di atas punggungnya, hal itu lebih baik daripada kalau ia meminta-minta kepada seorang yang kadangkadang diberi, kadang pula ditolak." (HR. Bukhari dan Muslim)

2 Afzalurrahman,Muhammad sebagai Seorang Pedagang, terjemahan dari Mubammad: Encyclopedia of Seerah, Jakarta: Yayasan Swarna Bhumi, 2000, hlm. 6-7.
} 
Dengan meneladani kehidupan Nabi Muhammad saw tersebut, seharusnya umat Islam tidak merasa tabu untuk menjadi wirausaha (pedagang). Di sinilah diperlukan peran berbagai pihak untuk mengkampanyekan gerakan wirausaha, terutama dari lembaga-lembaga yang berbasis Islam, baik formal maupun non formal sehingga umat Islam akan memiliki etos kerja yang tangguh. Etos kerja inilah yang menjadi kata kunci keberhasilan suatu usaha.

Etos kerja adalah kata majemuk yang terdiri dari dua kata dengan arti yang menyatu. Makna khas itu adalah bahwa etos kerja merupakan concern pragmatis. Ia membentuk perilaku individual dan sosial masyarakat. Dapat pula bermakna semangat kerja yang menjadi ciri khas dan keyakinan seseorang atau kelompok. ${ }^{3}$

Masyarakat ilmiah mempunyai pendapat dan batasan yang berbedabeda tentang etos kerja. Namun secara substansial mempunyai pengertian yang sama. Secara umum yang dimaksud dengan etos kerja adalah semangat kerja yang didasari oleh nilai-nilai atau norma-norma tertentu. Etos kerja juga bisa dimaknai sebagai sikap atau pandangan manusia terhadap kerja yang dilakukan dan yang dilatarbelakangi nilai-nilai yang diyakininya. Nilai-nilai itu dapat berasal dari suatu agama tertentu, adat istiadat, kebudayaan, serta peraturan perundang-undangan tertentu yang berlaku dalam suatu negara.

Sukriyanto, melalui tesisnya memberikan pengertian bahwa etos kerja adalah suatu semangat kerja yang dimiliki oleh masyarakat untuk mampu bekerja lebih baik guna memperoleh nilai hidup mereka. Karena etos kerja menentukan penilaian manusia yang diwujudkan dalam suatu pekerjaan, maka ia akan pula menentukan hasil-hasilnya. Dengan adanya keterkaitan yang erat antara etos kerja dengan survivalitas (daya tahan hidup) manusia di bidang ekonomi, maka dengan semakin progresif etos kerja suatu masyarakat juga akan semakin baik hasil-hasil yang dicapai baik secara kuantitatif maupun kualitatif. ${ }^{4}$

${ }^{3}$ Depdikbud, Kamus Besar Bahasa Indonesia, Jakarta: Depdikbud, 1988, hlm. 272.

${ }^{4}$ Sukiyanto, "Etos Kerja Salah Satu Faktor Survivalitas Peternak Sapi Perah: Studi Kasus di Desa Sidomulyo Kecamatan Batu Kota Batu Kabupaten Malang”, Tesis, Program Pasca Sarjana Universitas Muhammadiyah Malang, 2000, hlm. 92. 
Etos Kerja Pengusaha Muslim...

Etos kerja dapat juga berupa gerakan penilaian dan mempunyai gerak evaluatif pada tiap-tiap individu dan kelompok. Dengan evaluasi itu akan tercipta gerak grafik menanjak dan meningkat dalam waktu-waktu berikutnya. Ia juga bermakna cermin atau bahan pertimbangan yang dapat dijadikan pegangan bagi seseorang untuk menentukan langkah-langkah yang akan diambil kemudian. ${ }^{5}$ Ringkasnya, etos kerja adalah double standar of life yaitu sebagai daya dorong di satu sisi, dan daya nilai pada setiap individu atau kelompok pada sisi yang lain. Etos kerja, jika dikaitkan dengan agama berarti sikap atau pandangan atau semangat manusia terhadap kerja yang dilakukan, yang dipengaruhi oleh nilai-nilai agama yang dianutnya.

Nilai-nilai agama dan kultural dapat memberikan dorongan pada seseorang atau kelompok orang untuk mencapai prestasi tertentu, terutama dalam bidang ekonomi. ${ }^{6}$ Weber menegaskan hal itu. Pengaruh doktrin agama mendorong seseorang untuk meningkatkan kualitas hidup, seperti kualitas pemenuhan kebutuhan ekonomi. Motif religi yang mendorong keberhasilan hidup seseorang tersebut dapat dijumpai pada masyarakat Islam di Indonesia. Terdapat persamaan yang besar sekali antara etos kerja Protestan dengan etos kerja kaum santri pedagang. Terminologi etos kerja kaum santri pedagang tersebut menggambarkan keberhasilan para pengusaha muslim dalam mengembangkan usahanya di beberapa kota di Jawa pada tahun 1950-an, seperti Yogyakarta, Surakarta, Pekalongan, Tegal, Ponorogo dan kota lainnya. Pendapat itu didukung oleh Usman, yang menyatakan bahwa sejarah kehidupan masyarakat Indonesia memperlihatkan adanya keterkaitan yang signifikan antara kedalaman penghayatan agama dan kegairahan kehidupan ekonomi. ${ }^{7}$ Kelompok-kelompok tertentu yang tergolong menjalankan syariat agama dengan lebih bersungguh-sungguh, dalam kehidupan sosial dan pribadinya, kelihatan lebih mampu beradaptasi dalam kehidupan ekonomi.

5 Taufik Abdullah, (ed), "Tesis Weber dan Islam di Indonesia dalam Agama”, dalam Etos Kerja dan Perkembangan Ekonomi, cet. IV, Jakarta: LP3ES, 1988, hlm. 3.

6 Max Weber, Etika Protestan dan Semangat Kapitalisme (terjemahan), Penerbit Pustaka Promethea, 2000, hlm. 161.

7 Sunyoto Usman, Perkembangan dan Pemberdayaan Masyarakat, Yogyakarta: Penerbit Pustaka Pelajar, 1998, hlm. 99. 
Islam sebagai agama rahmatan li al-älamin, memberikan sumber-sumber normatif yang berkaitan dengan kerja, nilai kerja, dan etos kerja. ${ }^{8}$ Etos kerja harus didasarkan pada tiga unsur, yaitu tauhid, takwa, dan ibadah. Tauhid akan mendorong bahwa kerja dan hasil kerja adalah sarana untuk mentauhidkan Allah swt sehingga terhindar dari pemujaan terhadap materi. Takwa adalah sikap mental yang mendorong untuk selalu ingat, waspada, dan hati-hati memelihara dari noda dan dosa, menjaga keselamatan dengan melakukan yang baik dan menghindari yang buruk. Sedangkan ibadah adalah melaksanakan usaha atau kerja dalam rangka beribadah kepada Allah swt, sebagai perealisasian tugas khalifah fi al-ardh, untuk menjaga mencapai kesejahteraan dan ketentraman di dunia dan akhirat.

Etos kerja muslim didefinisikan sebagai sikap kepribadian yang melahirkan keyakinan yang sangat mendalam bahwa bekerja itu bukan saja untuk memuliakan dirinya, menampakkan kemanusiaannya, melainkan juga sebagai suatu manifestasi dari amal saleh. Sehingga bekerja yang didasarkan pada prinsip-prinsip iman bukan saja menunjukkan fitrah seorang muslim, melainkan sekaligus meninggikan martabat dirinya sebagai hamba Allah yang didera kerinduan untuk menjadikan dirinya sebagai sosok yang dapat dipercaya, menampilkan dirinya sebagai manusia yang amanah, menunjukkan sikap pengabdian sebagaimana firman Allah:

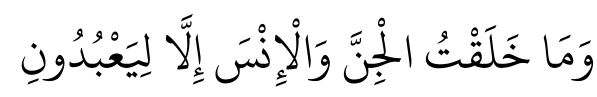

"Dan Aku tidak menciptakan jin dan manusia melainkan supaya mereka beribadah kepada-Ku." (QS. al-Dzariyat [51]:56)

Keterkaitan yang kuat antara agama Islam dengan aktifitas ekonomi umat, menurut Ismail adalah bahwa kegiatan ekonomi dalam Islam, meskipun konkritnya adalah kegiatan yang bersifat untuk mendapatkan kecukupan materi, tidak dapat dilepaskan dari kehidupan sesudah mati dan akan tetap dipertanggungjawabkan di hadapan Tuhan. ${ }^{9}$ Islam tidak mengajarkan satu sistem ekonomi yang komprehensif, tetapi Islam mengajarkan landasan etika

\footnotetext{
8 Prijono Tjiptoherijanto, "Etos Kerja dan Moral Pembangunan dalam Islam”, makalah tidak diterbitkan, 1988, hlm. 59-64.

${ }^{9}$ Munawar Ismail, "Islam Kapitalisme dan Sosialisme: Studi Komparatif Sistem Ekonomi”, Jurnal Lintasan Ekonomi, Edisi khusus Januari-April, Malang: Lembaga Penerbit Fakultas Ekonomi Universitas Brawijaya, 1997, hlm. 22.
} 
Etos Kerja Pengusaha Muslim...

dan moral bagi para pemeluknya yang akan melakukan kegiatan ekonomi. Islam pada prinsipnya mengajarkan kebaikan dan telah mengatur kehidupan umatnya di dunia dan di akhirat. Dalam prinsip etika ekonomi pada hakikatnya adalah menjalankan bisnis yang jujur sesuai dengan akidah agama. ${ }^{10}$ Senada dengan hal itu, Burhan menyatakan bahwa doktrin dalam Islam terkait erat dengan tujuan hidup manusia yang hakiki. ${ }^{11}$ Oleh karena itu, membicarakan tujuan manusia, dilihat dari kaca mata ekonomi, tidak dapat lepas dari tujuan hidup. Kegiatan ekonomi manusia menyatu dengan status manusia sebagai khalifah dan fungsi manusia untuk ibadah. Sebagai khalifah maka kegiatan ekonomi manusia harus dalam rangka memakmurkan seluruh penghuni bumi seraya menjaga kelestariannya, sedangkan dalam ibadah maka kegiatan tersebut hendaknya ditujukan untuk meningkatkan keimanan dan ketakwaan.

Terkait dengan semangat kewirausahaan di kalangan muslim, menurut pendapat Jaeroni Setyadhi, ${ }^{12}$ bahwa semangat kewirausahaan di kalangan muslim juga terlihat dari pepatah bahasa Arab "Inna al-samā là tumthiru dz̧ahaban wa là fidhdhatan" (Langit tidak menurunkan hujan emas dan perak, tetapi perlu dengan semangat kerja yang tidak mengenal lelah". Atau kata bijak yang bisa diimplementasikan ke kehidupan yang nyata "Isy ka annaka ta'isyu abada" atau "I'mal lid dun-yaka ka annaka ta'isyu abada". Di mana terminologi "bekerjalah bagi duniamu seakan-akan kamu hidup abadi" yang menunjukkan kepada semua orang bahwa etos kerja orang muslim sangat bisa untuk diandalkan. Hubungan sosiologi dari semangat etos kerja akan terlihat dari penghasilan, keuntungan dan akumulasi kapital. Di mana manusia merupakan khalifah di muka bumi yang mempergunakan semua sumber daya yang ada di sekitarnya untuk memenuhi keinginan yang relatif tidak terbatas dalam semangat kewirausahaan.

\footnotetext{
10 Mohamad Fadhely, Meneropong Kehidupan Ekonomi Umat Islam, Peradaban Islam, Kapitalis Budaya Cina di Indonesia, Jakarta: Penerbit Golden Press, 1995, hlm. 14.

11 Umar Burhan, "Memberdayakan Ekonomi Umat: Suatu Kajian Konsepsional dalam Beberapa Bukti Empiris", Jurnal Lintasan Ekonomi, Malang: Lembaga Penerbit Fakultas Ekonomi Universitas Brawijaya, 1997, hlm. 17

${ }^{12}$ Jaeroni Setyadhi, "Kewirausahaan Islam dan Bayang-bayang Orientalis Barat", IHB Jakarta, tanggal 20 September 2005, http/ /www.fajar.co.id.
} 
Berdasarkan uraian di atas, penelitian ini bertujuan untuk mengetahui bagaimana etos kerja pengusaha muslim alumni UIN Walisongo Semarang sehingga mereka mampu bertahan dalam menghadapi persaingan usaha dan relasi etos kerja para pengusaha muslim tersebut dengan kesuksesan usaha. Mereka layak diteliti karena mereka adalah lulusan UIN Walisongo Semarang, di mana UIN Walisongo Semarang adalah institusi perguruan tinggi yang berbasis pada nilai-nilai keislaman. Secara kelembagaan UIN Walisongo sendiri adalah perguruan tinggi negeri yang lahir dan didirikan oleh umat Islam dengan mendasarkan diri pada agama Islam. Sehingga dapat diasumsikan bahwa lulusan UIN Walisongo Semarang merupakan lulusan yang telah memahami nilai-nilai Islam secara käffah (paripurna) termasuk dalam hal perdagangan yang memerlukan etos kerja tinggi sebagaimana di contohkan Nabi Muhammad saw. Tetapi hal itu perlu dibuktikan, apakah benar bahwa mereka mampu bertahan di dunia bisnis karena memiliki etos kerja tinggi yang sejalan dengan etos kerja Islami sebagaimana yang diajarkan oleh Islam melalui keteladanan Nabi Muhammad saw. Penelitian ini akan menjawab pertanyaan tersebut.

\section{Tinjauan Pustaka}

Sudah cukup banyak penelitian ataupun artikel yang membahas mengenai etos kerja muslim ini. Di antaranya penelitian yang dilakukan oleh Khuzriyah dengan judul Etos Kerja Pedagang Sembako Muslim Pasar Bringharjo Yogyakarta. Penelitian ini bertujuan untuk mengetahui pandangan Islam terhadap etos kerja dan ada atau tidak pengaruh agama terhadap pedagang sembako muslim Pasar Bringharjo Yogyakarta. Melalui penelitian yang dilakukan dengan metode kualitatif dan dianalisis secara deskriptif dengan menggunakan pendekatan sosisologis tersebut, penulis menyimpulkan bahwa para pedagang sembako muslim Pasar Bringharjo Yogyakarta memiliki etos kerja yang baik, yang dimotivasi oleh motif biogenetis dan theogenetis. Motif biogenetis adalah dorongan untuk memenuhi kebutuhan biologis yang tercermin dari kegigihan para pedagang dalam mempertahankan dagangannya dari dulu hingga sekarang. Sementara motif theogenetis berupa keinginan manusia unuk berbakti kepada Tuhan, keinginan untuk melaksanakan perintah-perintah-Nya. Motif yang terakhir ini mendorong mereka untuk bekerja dan berusaha secara halal. 
Etos Kerja Pengusaha Muslim...

Penelitian selanjutnya berjudul Etos Kerja Karyawan Wanita Bagian Pevisi pada Indusri Kayu PT. Waroeng Batok Industri (WBI) Majenang Cilacap Jawa Tengah oleh Sukinah. Melalui penelitian kualitatif ini dapat diketahui bahwa karyawan wanita yang bekerja pada PT. WBI Majenang Jawa Tengah memiliki etos kerja yang baik. Hasil yang dicapai melalui etos kerja karyawan wanita ditampilkan dalam pemaknaan penilaian prestasi kerja, disiplin kerja, ketekunan dalam bekerja, dan kondisi kerja.

Acep Mulyadi juga meneliti tentang Islam dan Etos Kerja: Relasi Antara Kualitas Keagamaan dengan Etos Produktivitas Kerja di Daerah Kawasan Industri Kabupaten Bekasi. ${ }^{13}$ Penelitian ini merupakan kelanjutan dari studi-studi sosiologi sejak Max Weber hingga penelitian-penelitian manajemen belakangan yang semuanya bermuara pada satu kesimpulan bersama bahwa, keberhasilan di berbagai wilayah kehidupan ternyata ditentukan oleh perilaku manusia, terutama perilaku kerja. Perilaku kerja atau etos kerja merupakan dasar utama bagi kesuksesan yang sejati dan autentik. Melalui pendekatan kualitatif dan kuantitatif dengan memfokuskan pada aspek ritual (ritual involvement), ideologi (ideological involvement), intelektual (intellectual involvement), pengalaman (experience involvement), aspek konsekuensi sikap dan komitmennya terhadap ajaran agama (consequential involvement).

Penelitian ini berusaha mengungkap apakah ada korelasi positif antara agama dengan etos kerja. Atau dengan kata lain, apakah kesalehan ritual dengan maraknya kegiataan keagamaan terejawantahkan menjadi kesalehan sosial dalam bentuk etos kerja. Penelitian ini adalah penelitian lapangan dengan menggunakan pendekatan kualitatif kuantitatif untuk memperkuat temuan-temuan yang diperoleh dari nara sumber dan data lapangan. Pendekatan kualitatif digunakan untuk menemukan kecenderungan yang tidak bisa dikuantifikasi dengan angka-angka, sedangkan pendekatan kuantitatif diperlukan untuk mendukung kecenderungan yang terungkap melalui pendekatan kualitatif.

13 Acep Mulyadi, "Islam dan Etos Kerja: Relasi Antara Kualitas Keagamaan dengan Etos Produktivitas Kerja di Daerah Kawasan Industri Kabupaten Bekasi”, Jurnal Turats, Vol. 4 No. 1, Juni 2008. 
Jika mencermati hasil penelitian ataupun artikel tentang etos kerja muslim sebagaimana diuraikan di atas, maka penelitian ini memiliki perbedaan dengan penelitian sebelumnya, yaitu pada obyek penelitiannya yang meneliti para pengusaha alumni UIN Walisongo Semarang dengan lokus penelitian di Kota Semarang.

\section{Tujuan Penelitian}

Tujuan dari penelitian ini adalah untuk mengetahui secara mendalam etos kerja pengusaha muslim yang dapat dijadikan sebagai acuan bagi para pengusaha, khususnya pengusaha muslim yang ingin mengembangkan usahanya melalui penerapan etos kerja berdasarkan nilai-nilai Islam.

\section{Metodologi}

Jenis penelitian ini adalah penelitian lapangan (field research) yang bersifat kualitatif. ${ }^{14}$ Sumber data berupa sumber data primer ${ }^{15}$ dan sekunder. ${ }^{16}$ Data primer diperoleh dengan melakukan wawancara dan observasi terhadap para pengusaha muslim alumni UIN Walisongo Semarang. Sedangkan data sekunder diperoleh melalui buku-buku, internet, makalah-makalah dan jurnal yang relevan. Studi dokumen resmi yang dilakukan peneliti adalah mengumpulkan data melalui pencatatan atau data-data tertulis mengenai etos kerja para pengusaha muslim alumni UIN Walisongo Semarang.

Metode pengumpulan data dilakukan dengan wawancara dan observasi. Wawancara dilakuan terhadap para pengusaha muslim alumni UIN Walisongo Semarang dan juga konsumen (customer) yang pernah menjalin bisnis (hubungan bisnis) dengan para pengusaha muslim alumni UIN Walisongo Semarang. Metode wawancara yang digunakan dalam penelitian ini adalah wawancara semiterstruktur (semistructure interview) dimana peneliti

\footnotetext{
14 Metodologi kualitatif adalah sebagai prosedur penelitian yang menghasilkan data deskriptif berupa kata-kata tertulis atau lisan dari orang-orang dan perilaku yang diamati (Robert Bogdan and Steven J. Taylor, Introduction to Qualitative Research Methods, New York: 1975, hlm. 4).

${ }_{15}$ Data primer adalah data langsung yang diperoleh si peneliti dari sumber data untuk tujuan yang khusus. (Winarno Surahmad, Pengantar Penelitian-penelitian Ilmiah, Dasar Metoda Teknik, Edisi 7, Bandung: Tarsito, 1989, hlm. 134-163).

16 Data sekunder adalah data yang telah lebih dahulu dikumpulkan oleh orang di luar diri peneliti sendiri, walaupun yang dikumpulkan itu sesungguhnya adalah data yang asli (Ibid)
} 
Etos Kerja Pengusaha Muslim...

menyiapkan pertanyaan-pertanyaan terlebih dahulu, akan tetapi pelaksanaannya lebih bebas dan tidak menutup kemungkinan untuk munculnya pertanyaan-pertanyaan baru yang masih relevan guna memperoleh pendapat dan ide dari narasumber secara lebih luas. ${ }^{17}$ Observasi yang peneliti lakukan adalah observasi partisipasi pasif, artinya peneliti datang ke lokasi penelitian, tetapi tidak ikut terlibat dalam aktivitas (bisnis) yang dilakukan oleh objek yang diamati. ${ }^{18}$ Dalam hal ini, peneliti melakukan pengamatan secara langsung di lapangan dan mencatat kejadian-kejadian yang berkaitan dengan etos kerja pengusaha muslim alumni UIN Walisongo Semarang serta mengamati setiap proses bisnis yang berlangsung.

Analisis yang digunakan pada penelitian ini adalah deskriptif analisis, yaitu analisa atas data yang merupakan proses pelacakan dan pengaturan yang tersusun secara sistematis melalui transkrip wawancara, catatan lapangan, dan bahan-bahan lain yang dikumpulkan untuk meningkatkan pemahaman terhadap bahan-bahan tersebut sehingga dapat dipresentasikan semuanya kepada orang lain. Analisa dilakukan sebelum ke lapangan, selama di lapangan, saat pengumpulan data dan setelah selesai mengumpulkan data. Dalam diskriptif analisis peneliti mengarahkan pada pemahaman tentang etos kerja para pengusaha muslim alumni UIN Walisongo Semarang. Selain pengklasifikasian tersebut peneliti juga memetakan relasi antara etos kerja dengan kesuksesaan bisnis yang dijalankan oleh para pengusaha muslim alumni UIN Walisongo Semarang.

\section{Hasil dan Pembahasan}

Belum ada angka pasti secara statistik berapa jumlah alumni UIN Walisongo Semarang yang menjadi pengusaha. Namun dari beberapa komunikasi dan observasi lapangan dari beberapa pengusaha alumni UIN Walisongo Semarang yang dapat ditemui, jumlah pengusaha alumni UIN Walisongo Semarang belum signifikan. Alumni UIN Walisongo Semarang masih dominan menjadi pegawai/karyawan di instansi pemerintahan maupun swasta. Tabel 1 di bawah ini menunjukkan daftar beberapa nama pengusaha

\footnotetext{
${ }^{17}$ Ibid, hlm. 233.

18 Sugiyono, Metode Penelitian Kuantitatif, Kualitatif dan R \& D, Bandung: Penerbit Alfabeta, hlm. 227.
} 
muslim alumni UIN Walisongo Semarang yang tinggal di Kota Semarang yang dapat peneliti temui. Mereka sekaligus menjadi informan kunci dalam penelitian ini.

Tabel 1

Daftar Pengusaha Muslim Alumni UIN Walisongo Semarang yang bertempat tinggal di Kota Semarang

\begin{tabular}{|c|c|c|c|c|}
\hline No & Nama & Alamat & Fak. & Usaha \\
\hline 1 & M. Luthfi & $\begin{array}{l}\text { Jl. Honggo Wongso Ngaliyan } \\
\text { Semarang }\end{array}$ & FS/ 89 & Meubel \\
\hline 2 & Helmi Suyanto & $\begin{array}{l}\text { Taman Beringin Mulia No. } 35 \\
\text { Semarang }\end{array}$ & FT/90 & $\begin{array}{l}\text { Design } \\
\text { Grafis }\end{array}$ \\
\hline 3 & Umi Syarifah & $\begin{array}{l}\text { Perum. Bukit Beringin Asri } \\
\text { D. } 20 \text { Ngaliyan Semarang }\end{array}$ & FS/97 & Es krim \\
\hline 4 & M. Fahmi & Perum Jatisari Asri A3 No.1 & FT/08 & Laundry \\
\hline 5 & Solihin & Jl. Prof. Dr. Hamka Ngaliyan & $\mathrm{FD} / 86$ & Fotokopi \\
\hline 6 & Ahmad Nasikhin & Perum BPI E.8 Ngaliyan & FS/94 & $\begin{array}{l}\text { Warung } \\
\text { Penyet }\end{array}$ \\
\hline 7 & Sujiantoko & $\begin{array}{l}\text { Jl. Tanjungsari Barat RT } 7 \\
\text { RW } 5 \text { Ngaliyan Semarang }\end{array}$ & FS/03 & $\begin{array}{l}\text { Design } \\
\text { grafis dan } \\
\text { Cetak }\end{array}$ \\
\hline 8 & A. Yusuf Isnan S. & $\begin{array}{l}\text { Jl. Honggo Wongso No. } 9 \\
\text { Ngaliyan Semarang }\end{array}$ & FT/94 & $\begin{array}{l}\text { Rumah } \\
\text { Makan }\end{array}$ \\
\hline 9 & Widodo Budi U & $\begin{array}{l}\text { Karonsih Baru No. } 41 \text { RT } 12 \\
\text { RW } 3 \text { Ngaliyan Semarang }\end{array}$ & FS/94 & $\begin{array}{l}\text { Toko } \\
\text { Pakaian }\end{array}$ \\
\hline 10 & Hendro & $\begin{array}{l}\text { Jl. Raya Ngaliyan No. } 125 \\
\text { Semarang }\end{array}$ & FT/92 & $\begin{array}{l}\text { Bangkel } \\
\text { Mobil }\end{array}$ \\
\hline 11 & Ummu Jauharin Farda & $\begin{array}{l}\text { Jl. Bukit Beringin Asri Gg. } 7 \\
\text { No. } 218 \text { Semarang }\end{array}$ & FT/94 & $\begin{array}{l}\text { Warung } \\
\text { Makan dan } \\
\text { Katering }\end{array}$ \\
\hline 12 & Fauziyah Wildan & Perum. BPI D.1 Semarang & $\mathrm{FS} / 91$ & $\begin{array}{l}\text { WO dan } \\
\text { rias } \\
\text { pengantin }\end{array}$ \\
\hline 13 & Fauzan & $\begin{array}{l}\text { Margoyoso } 1 \text { No. } 17 \text { RT } 4 \\
\text { RW } 4 \text { Ngaliyan Semarang }\end{array}$ & FT/03 & $\begin{array}{l}\text { Jual Susu } \\
\text { Sapi Murni }\end{array}$ \\
\hline 14 & Hasyim Syarbani & $\begin{array}{l}\text { Jl. Pelem Kweni No. } 8 \text { RT } \\
\text { 07RW } 02 \text { Tambakaji Ngaliyan } \\
\text { Semarang }\end{array}$ & FS/76 & $\begin{array}{l}\text { Toko } \\
\text { Bangunan }+ \\
\text { Property }\end{array}$ \\
\hline 15 & Abdul Wahab & $\begin{array}{l}\text { Pandean Taman Harjo Mataram } \\
\text { Semarang }\end{array}$ & $\mathrm{FU} / 90$ & Toko Jam \\
\hline
\end{tabular}

Keterangan:

FT = Fakultas Tarbiyah

FS $\quad=$ Fakultas Syariah
FD $\quad=$ Fakultas Dakwah

FU = Fakultas Ushuluddin 
Etos Kerja Pengusaha Muslim...

Alasan yang cukup kuat untuk memilih para responden tersebut adalah karena masing-masing responden telah mewakili jenis usaha yang ada. Bapak Muhammad Luthfi dianggap mewakili pengusaha muslim alumni UIN Walisongo yang bergerak di bidang meubel, Bapak Helmi Suyanto dan Bapak Sujiantoko dianggap mewakili pengusaha muslim alumni UIN Walisongo yang bergerak di bidang design grafis dan percetakan, Ibu Umi Syarifah dianggap mewakili pengusaha muslim alumni UIN Walisongo yang bergerak di bidang penjualan minuman (es krim), Bapak M. Fahmi dianggap mewakili pengusaha muslim alumni UIN Walisongo yang bergerak di bidang layanan jasa laundry, Bapak Solihin dianggap mewakili pengusaha muslim alumni UIN Walisongo bergerak di bidang usaha layanan foto kopi, Bapak Ahmad Nasikhin dianggap mewakili pengusaha muslim alumni UIN Walisongo yang bergerak di bidang penjualan makanan cepat saji (warung penyet), Bapak M. Yusuf Isnan S. dianggap mewakili pengusaha muslim alumni UIN Walisongo yang bergerak di bidang penyediaan sarana kolam pancing dan rumah makan, Bapak Widodo Budi Utomo dianggap mewakili pengusaha muslim alumni UIN Walisongo yang bergerak di bidang penjualan pakaian, Bapak Hendro dianggap mewakili pengusaha muslim alumni UIN Walisongo yang bergerak di bidang layanan jasa bengkel mobil, Ibu Ummu Jauharin F (Ibu Ririn) dianggap mewakili pengusaha muslim alumni UIN Walisongo yang bergerak di bidang warung makan dan katering, Ibu Fauziah Wildan dianggap mewakili pengusaha muslim alumni UIN Walisongo yang bergerak di bidang Wedding Organizer (WO) dan rias pengantin, Bapak Fauzan dianggap mewakili pengusaha muslim alumni UIN Walisongo yang bergerak di bidang penjualan minuman Susu murni, Bapak Hasyim Syarbani dianggap mewakili pengusaha muslim alumni UIN Walisongo yang bergerak di bidang penjualan barang bangunan dan property, dan Bapak Abdul Wahab dianggap mewakili pengusaha muslim alumni UIN Walisongo yang bergerak di bidang penjualan aneka jam.

\section{Semangat Wirausaha dan Etos Kerja Pengusaha Muslim Alumni UIN Walisongo Semarang}

Semangat bekerja adalah bagian dari karakter wirausaha. Wirausaha mensyaratkan semangat bekerja yang prima. Semangat ini mengandung 
beberapa maksud, antara lain bekerja keras, pantang menyerah dan tidak mudah putus asa. Hal itulah yang mendasari etos kerja para pelaku wirausaha.

Bagi pengusaha muslim alumni UIN Walisongo Semarang, semangat bekerja menjadi salah satu nilai yang inheren, menyatu pada dirinya dalam menjalankan usaha. Hal itu dapat ditemukan dari konsistensi para pengusaha muslim alumni UIN Walisongo Semarang yang hingga saat ini masih terus menjalankan usahanya. Bapak M. Luthfi misalnya, yang membuka usaha meubel selalu bekerja dengan antusias dan bersemangat dalam menjalankan usahanya. Tidak ada kata malas dalam kamus hidupnya. Bagi pengusaha, terus bergerak dengan semangat yang prima adalah modal awal menjalankan dan mensukseskan usaha. ${ }^{19} \mathrm{Hal}$ itu diamini oleh Bapak Fauzan, Bapak Hendro, Bapak Ahmad Nasihin, Bapak Solihin, Ibu Umi Syarifah, Bapak Abdul Wahab dan juga responden lainnya.

Apabila dicermati secara mendalam, semangat bekerja keras sebagai bagian dari etos kerja seorang pengusaha, paling tidak dilatarbelakangi oleh dua faktor, yaitu pandangan mereka tentang bekerja dan alasan pemilihan profesi bisnis sebagai lahan penghasilan. Dari dua pandangan itu akan tergambarkan sejauh mana kualitas etos kerja seorang pengusaha.

Bekerja menurut Islam, pada dasarnya adalah bagian dari ibadah kepada Allah swt. Selain bekerja adalah cara untuk mempertahankan hidup di dunia, mencari kebahagiaan dan aktualisasi diri sebagai manusia yang membutuhkan pengakuan, ia adalah bagian dari perwujudan pengabdian manusia kepada Allah swt yang telah memberikan kesempatan berkarya. Semangat inilah yang menginspirasi seseorang untuk terus menjalankan aktivitas hidupnya. Demikian pula halnya dengan para pengusaha muslim alumni UIN Walisongo Semarang. Disadari atupun tidak, mereka telah mendedikasikan dirinya dalam lingkaran semangat semacam itu. Hal itu terbukti dari beberapa hasil wawancara dengan mereka.

Bapak Luthfi menyatakan bahwa dalam menjalankan usaha, semua tidak lepas dari keterlibatan Allah. Sukses tidaknya seorang pengusaha

${ }^{19}$ Wawancara dengan Bapak M. Luthfi, Senin, 20 Juli 2015. 
tergantung pada sejauh mana ia melibatkan Allah dalam bisnisnya. ${ }^{20} \mathrm{Hal}$ itu sepaham dengan apa yang disampaikan oleh Bapak Hasyim Syarbani, Ibu Ririn, Ibu Umi Syarifah, Bapak Helmi Suyanto, Bapak M. Fahmi, dan lainlain. ${ }^{21}$ Namun, ada satu hal yang perlu dipahami, bahwa ukuran suksesnya pengusaha itu bisa berbeda antara satu orang dengan yang lainnya. Salah satu indikator kesuksesan yang paling mudah diamati adalah suksesnya pengusaha dalam keterlibatannya di kehidupan sosial. Artinya, suksesnya pengusaha berbanding lurus dengan keterlibatan mereka dalam kehidupan sosial keagamaan. Hasil yang mereka peroleh, selain untuk memenuhi kebutuhan hidup dan pengembangan usaha, juga dipergunakan untuk membantu pihakpihak yang memerlukan bantuan, seperti panti asuhan, pesantren, lembaga sosial keagamaan, dan lain-lain. Tentu hal itu dilakukan sesuai dengan tingkat kesuksesan masing-masing. Inilah yang dimaksudkan dengan konsep "sebaikbaik manusia adalah yang bermanfaat bagi manusia yang lainnya."22

Keterlibatan dalam ranah sosial kegamaan misalnya tercermin dari apa yang dilakukan oleh Bapak Hendro dengan kegiatan santunan pada karyawan yang membutuhkan bantuan, pengadaan kegiatan wisata bersama karyawan dan keluarga untuk meningkatkan kebersamaan, serta mengunjungi beberapa tempat bersejarah dalam Islam seperti masjid dan makam para wali serta panti yatim piatu. Kegiatan itu secara inspiratif mampu mendorong pengusaha untuk terus bekerja dengan penuh semangat. ${ }^{23}$ Dalam konteks sosial tersebut, Bapak M. Lutfi mendedikasikan sebagian rejekinya untuk mendirikan mushalla, pesantren dan sekolah Islam. Menurut beliau, bekerja itu tidaklah sekedar mencari uang, tetapi juga berbagi dengan sesama. ${ }^{24}$ Tidak jauh berbeda dengan Bapak M. Luthfi, Bapak Widodo Budi Utomo juga sampai saat ini masih memiliki anak asuh yang setiap bulan beliau menanggung biaya

\footnotetext{
${ }^{20}$ Wawancara dengan Bapak M. Luthfi, Senin, 20 Juli 2015.

${ }^{21}$ Wawancara dengan beberapa pengusaha muslim alumni UIN Walisongo Semarang

${ }^{22}$ Wawancara dengan Bapak Hasyim Syarbani, Bapak Luthfi, Bapak Hendro, Bapak Widodo Budi Utomo, Ibu Ririn, Bapak Abdul Wahab, Bapak Helmi Suyanto.

${ }^{23}$ Wawancara dengan Bapak Hendro, Kamis, 27 Agustus 2015.

24 Wawancara dengan Bapak M. Luthfi, Senin, 20 Juli 2015.
} 
kehidupan dan sekolahnya. Bahkan dalam waktu dekat beliau akan mendirikan yayasan untuk menaungi beberapa anak asuhnya itu. ${ }^{25}$

Ketika pandangan seseorang tentang kerja itu adalah bagian dari ibadah, maka apa yang mereka kerjakan tidak semata-mata mencari uang atau untung untuk mencukupi kebutuhan dunia. Dalam hal ini muncullah konsep kerja sebagai jihad. Jika kerja itu adalah ibadah dan bagian dari jihad, maka seorang muslim tersebut telah memiliki semangat etos kerja yang senafas dengan nilai-nilai Islam.

Islam memandang bekerja yang dilakukan secara halal adalah jihad, sebagaimana hadis Rasulullah saw, "Mencari yang halal adalah bagian dari jihad.” (HR. Tirmidzi). Al-Qur'an juga memandang bekerja keras sebagai aktifitas yang sangat penting. Hal itu di antaranya terdapat dalam QS. al-Nisa' [4]:95.26 Bahkan al-Qur'an memandang orang yang bekerja keras itu sedang meniti jalan untuk menemui Tuhannya (QS. al-Insyiqaq [84]:6). 27 Prinsip inilah yang melahirkan konsep etos kerja seorang muslim.

Etos kerja muslim tercerminkan pada sikap kepribadian yang melahirkan keyakinan yang sangat mendalam bahwa bekerja itu bukan saja untuk memuliakan dirinya, menampakkan kemanusiaannya, melainkan juga sebagai suatu manifestasi dari amal saleh. Sehingga bekerja yang didasarkan pada prinsip-prinsip iman bukan saja menunjukkan fitrah seorang muslim, melainkan sekaligus meninggikan martabat dirinya sebagai hamba Allah yang didera kerinduan untuk menjadikan dirinya sebagai sosok yang dapat dipercaya, menampilkan dirinya sebagai manusia yang amanah, menunjukkan sikap pengabdian, sebagaimana firman Allah dalam QS. al-Dzariyat [51]: 56.

Hal kedua yang mempengaruhi semangat dalam bekerja sebagai bagian dari etos kerja adalah pemilihan profesi bisnis sebagai lahan mengais rejeki.

25 Wawancara dengan Bapak Widodo Budi Utomo, Senin, 10 Agustus 2015.

26 Artinya: "Tidaklah sama antara mukmin yang duduk (yang tidak ikut berperang) yang tidak mempunyai uzur dengan orang-orang yang berjihad di jalan Allah dengan harta mereka dan jiwanya. Allah melebihkan orang-orang yang berjihad dengan harta dan jiwanya atas orang-orang yang duduk satu derajat. Kepada masing-masing mereka Allah menjanjikan pahala yang baik (surga) dan Allah melebihkan orang-orang yang berjihad atas orang yang duduk dengan pahala yang besar."

27 Artinya: "Wahai manusia, sesungguhnya kamu bekerja keras menuju Tuhanmu, maka kamu akan menemui-Nya." 
Etos Kerja Pengusaha Muslim...

Pemilihan terhadap sesuatu mengindikasikan adanya ketertarikan terhadap sesuatu itu. Sesuatu yang dilakukan karena ada ketertarikan maka akan menghasilkan semangat (dorongan) tersendiri untuk menjalankannya.

Dari para pengusaha muslim alumni UIN Walisongo Semarang, alasan mengapa mereka memilih bisnis sebagai profesinya memang bervariasi. Sebagian ada yang murni karena hobi dan berbisnis itu adalah pilihan, sementara sebagian yang lain karena terpaksa, karena mengingat saat itu mereka belum memiliki pekerjaan. Sebagai contoh untuk alasan yang kedua, dimana saat awal memulai bisnis itu karena alasan terpaksa adalah seperti apa yang disampaikan oleh Bapak Ahmad Nasihin. Sebenarnya beliau tidak pernah memiliki cita-cita untuk menjadi pengusaha. Namun karena beliau sering ditolak ketika melamar pekerjaan, maka akhirnya beliau menerjuni usaha membuka warung penyet. Itu pun sempat terhenti selama dua tahun karena beliau mencoba bekerja di sebuah instansi yang ada di kota Rembang, meskipun akhirnya keluar juga dari pekerjaan tersebut karena ternyata tidak cocok untuk menjadi orang gajian. Beliau kembali melanjutkan usaha warung penyet. Kebetulan saat beliau berhenti bekerja, ada tawaran lokasi dan alih usaha warung penyet dari temannya. Pucuk dicinta ulam pun tiba. Saat beliau membutuhkan pekerjaan, peluang usaha pun terbuka di depan mata. Itulah yang namanya rejeki. Namun meskipun awalnya ada keterpaksaan menjalankan usaha, kini beliau bersyukur karena usaha yang ditekuninya telah banyak membuahkan hasil. Dari usaha tersebut, beliau bisa membeli rumah, tanah, dan kendaraan, selain untuk membiayai kehidupan keluarganya. Mulai dari nol sampai kondisi saat ini, apa yang diraihnya adalah sebuah capaian prestasi yang patut dihargai. Kuncinya adalah tetap terus menjalankan usaha, tanpa ada kata putus asa dan bekerja dengan penuh semangat. Itulah komitmen yang dibangun oleh Bapak Ahmad Nasihin. ${ }^{28}$

Alasan yang sama disampaikan oleh Bapak M. Fahmi, yang sempat ikut ujian seleksi peneriman pegawai administrasi di UIN Walisongo Semarang. Akan tetapi beliau gagal dalam seleksi tersebut. Namun rupanya kegagalan itu adalah awal yang baik baginya. Beliau mulai merintis usaha percetakan, bekerjasama dengan beberapa percetakan rekanannya. Meskipun

${ }^{28}$ Wawancara dengan Bapak Ahmad Nasihin, Sabtu, 8 Agustus 2015. 
usaha tersebut tidak berjalan lama, namun pengalamannya dalam jasa percetakan menjadi bekal yang sangat bermanfaat kelak di kemudian hari. Terbukti setelah menekuni usaha laundry selama beberapa tahun, usaha percetakan yang dahulu pernah berhenti, kini dijalankan kembali olehnya. Bahkan saat ini beliau sudah memiliki mesin cetak sendiri. Semua tergantung pada upayanya dalam menjalankan usaha. Semakin percaya diri dan optimis, maka usaha yang digeluti akan menghasilkan seperti apa yang diharapkan. Inilah kunci etos kerja yang baik. ${ }^{29}$

Berbeda dengan dua kasus di atas, pengalaman awal memulai usaha (berbisnis) sebagai jalan hidup yang dipilih dan bukan karena keterpaksaan lebih banyak ditemukan dari para pengusaha muslim alumni UIN Walisongo Semarang. Bapak Hasyim Syarbani, pengusaha sekaligus dosen UIN Walisongo Semarang adalah salah satu contohnya. Beliau sejak muda sudah berbisnis. Tidak ada kata terpaksa dalam menjalankan bisnis. Bisnis adalah pilihan dan hingga kini beliau masih tetap bersemangat menjalankan bisnis yang dijalankan, yaitu usaha toko bangunan dan properti. ${ }^{30}$

Demikian pula dengan Ibu Umi Syarifah, Ibu Faizah Wildan, Bapak Fauzan, Bapak Solihin, Bapak Hendro, Bapak M. Luthfi dan responden lainnya. Menariknya, Bapak Fauzan yang lulusan Fakultas Ilmu Tarbiyah dan Keguruan (FKIP) UIN Walisongo Semarang saat ini sangat antusias untuk berbagi pengalaman dengan para mahasiswa UIN Walisongo Semarang agar mereka tidak bercita-cita untuk menjadi orang gajian atau menjadi pegawai negeri/swasta. Bisnis harus menjadi pilihan terbaik karena dengan bisnis inilah problem bangsa akan ikut teratasi, terutama problem sempitnya lapangan pekerjaan dan menjamurnya pengangguran. Tidak heran jika Bapak Fauzan sangat menyambut baik jika diminta berbicara di hadapan mahasiswa UIN Walisongo Semarang untuk berbagi ilmu tentang pengalaman bisnis. ${ }^{31}$

Hal senada juga disampaikan oleh Bapak Sujiantoko. Meskipun saat ini beliau menjadikan bisnis sebagai usaha paruh waktu, karena beliau juga menjadi staf administrasi di Fakultas Ekonomi dan Bisnis Islam, namun

\footnotetext{
${ }^{29}$ Wawancara dengan Bapak M. Fahmi, Sabtu, 15 Agustus 2015.

30 Wawancara dengan Bapak Hasyim Syarbani, Selasa, 8 September 2015.

31 Wawancara dengan Bapak Fauzan, Sabtu, 22 Agustus 2015.
} 
menjalankan bisnis/usaha itu baginya adalah pilihan, bukan keterpaksaan. Kesukaannya terhadap bisnis membuat beliau tidak bisa meninggalkan dunia ini. Dalam kondisi apa pun beliau tetap berusaha untuk bisa menjalankan usahanya. Tak ayal, beliau sering bekerja lembur untuk mengerjakan proyek dari para pelanggannya. Namun semuanya dijalani dengan senang hati dan penuh semangat. Hal itu bisa beliau lakukan karena saat memulai usaha didasari oleh rasa suka, hobi dan bukan karena keterpaksaan. ${ }^{32}$

Tidak jauh berbeda dengan apa yang diutarakan oleh Bapak Widodo Budi Utomo. Meskipun beliau saat ini menduduki jabatan prestisius di sebuah perusahaan penerbitan, namun beliau masih bisa mengelola usaha butiknya. Awalnya karena suka, dilaksanakan dengan penuh semangat dan akhirnya dapat menghasilkan sebagaimana apa yang diharapkan. ${ }^{33}$

Dari pandangan para pengusaha muslim alumni UIN Walisongo Semarang tentang dua hal tersebut di atas, yaitu tentang makna bekerja dan alasan pemilihan bisnis sebagai lahan penghasilan dapat menunjukkan kepada kita atas pemahaman mereka yang sebenarnya tentang etos kerja.

Bagi pengusaha muslim alumni UIN Walisongo Semarang, etos kerja tidak mereka pahami secara utuh dalam kerangka teoritis. Mereka menjalankan usaha secara natural, dimana apa yang mereka praktikkan justru sudah menerminkan unsur-unsur yang ada pada etos kerja seorang muslim, seperti bekerja keras, semangat, tidak putus asa, dan memandang kerja sebagai sebuah ibadah kepada Allah swt.

Etos kerja menurut pengusaha muslim alumni UIN Walisongo Semarang memiliki makna yang berbeda-beda tergantung siapa yang menjalaninya. Perbedaan itu terdapat pada istilah yang digunakan, tidak pada tataran aplikasinya. Ada di antara pengusaha muslim alumni UIN Walisongo Semarang yang memaknai etos kerja sebagai semangat kerja, ${ }^{34}$ ada yang

\footnotetext{
32 Wawancara dengan Bapak Sujiantoko, Kamis, 20 Agustus 2015.

${ }^{33}$ Wawancara dengan Bapak Widodo Budi Utomo, Senin, 10 Agustus 2015.

34 Wawancara dengan Bapak Hasyim Syarbani, Bapak Luthfi, Bapak Hendro, Ibu Ririn, dan Bapak Yusuf Isnan.
} 
memaknainya sebagai gairah berusaha, ${ }^{35}$ ada pula yang memaknainya sebagai keseriusan dalam menjalankan pekerjaan. ${ }^{36}$

Masing-masing istilah yang digunakan sebagaimana tersebut di atas tidaklah muncul begitu saja, tanpa ada alasan yang melatarbelakanginya. Tidak semua pengusaha muslim alumni UIN Walisongo Semarang pernah belajar mengenai teori ekonomi selayaknya para akademisi di bidang ekonomi, khususnya tentang teori etos kerja. Namun mereka belajar mempraktikkan bisnis secara otodidak (learning by doing), melalui tempaan rintangan dan hambatan. Hal itu berujung pada realisasinya. Secara aplikatif, istilah etos kerja tidak dipahami selayaknya berbagai teori tentang etos kerja yang sudah ada di berbagai buku-buku formal yang memuat pendapat para ahli mengenai hal itu. Para pengusaha muslim alumni UIN Walisongo Semarang lebih menonjolkan aspek riilnya dibanding dengan teori yang ada. Bagi mereka teori hanyalah penopang, sementara yang paling utama adalah praktiknya. Hal itu juga dapat menjadi sindiran bagi para akademisi yang mungkin lebih banyak berkutat pada kehebatan teori tetapi minim praktik. Meskipun sebenarnya semua tergantung pada wilayah pekerjaan yang sedang ditekuni. Ada pihak-pihak yang harus membangun teori guna memantapkan bangunan ilmu ekonomi Islam (bisnis Islam) secara baik, tetapi ada juga pihak-pihak yang mempraktikkan teori itu dalam tataran praktis sebagai upaya untuk merealisasikan bangunan ilmu ekonomi Islam (bisnis Islam) yang rabmatan li al-älamin.

\section{Etos Kerja dan Keberhasilan Usaha Pengusaha Muslim Alumni UIN Walisongo Semarang}

Pengusaha muslim alumni UIN Walisongo Semarang dengan berbagai latar belakang usaha yang dijalaninya telah mampu mempertahankan usahanya hingga sekarang. Salah satu kuncinya adalah adanya semangat etos kerja yang terpelihara dengan baik. Etos kerja tersebut telah mampu

35 Wawancara dengan Ibu Fauziyah Wildan, Ibu Umi Syarifah, Bapak Sujiantoko, Bapak M. Fahmi, dan Bapak Helmi Suyanto.

36 Wawancara dengan Bapak Ahmad Nasihin, Bapak Widodo Budi Utomo, Bapak Fauzan, Bapak Abdul Wahab, dan Bapak Sujiantoko. 
Etos Kerja Pengusaha Muslim...

mendorong perkembangan usaha mereka sekalipun dalam kadar yang berbeda-beda.

Pertanyannya, benarkah secara nyata etos kerja yang mereka pahami dan praktikkan telah mampu mendongkrak perkembangan usaha yang dijalani? Meskipun tidak dijelaskan secara detail berupa angka-angka yang sifatnya lebih pasti, namun dari beberapa wawancara yang peneliti lakukan, tergambar bagaimana perkembangan usaha yang mereka jalankan.

Bapak M. Luthfi, secara antusias memberikan gambaran perkembangan usahanya. Saat awal mula menjalankan usaha meubel, beliau belum memiliki tempat yang representatif. Pada awal-awal menekuni usaha ini, pameran dan promosi beliau lakukan secara terus menerus untuk mendongkrak penjualan, meskipun saat itu beliau masih pendatang baru di usaha meubel di tengah banyaknya pesaing yang telah lebih dahulu eksis di usaha yang sama. Beliau tanpa kenal lelah memasarkan sendiri sampai ke luar kota Semarang. Semua dilakukan dengan keinginan untuk memajukan usaha yang dibangunnya. Maka tak heran, baru berjalan beberapa tahun, usaha toko meubelnya telah berkembang dengan cepat. Tidak lebih dari 5 tahun menjalankan usaha ini beliau sudah memiliki 10 toko meubel di beberapa kota di Jawa Tengah, seperti di Semarang, Kendal, Cepiring, dan Tegal.

Namun 10 toko meubel miliknya kini tinggal 4 toko. Sengaja beliau menutup beberapa toko tersebut karena keinginannya untuk membuka pabrik sofa. Menurut perhitungannya, dengan memiliki pabrik sofa, omset yang beliau dapatkan akan jauh lebih besar dibandingkan dengan hanya melayani penjualan melalui toko mebel. Dan ternyata apa yang beliau perhitungkan itu terbukti. Setelah beliau membuka pabrik sofa, yang lokasinya tidak jauh dari lokasi toko meubelnya yang berada di Jl. Honggowongso Ngaliyan, omsetnya dalam 1 bulan bisa melebihi omset satu tokonya dalam 1 tahun. Hal itu karena dengan mendirikan pabrik, beliau dapat melayani permintaan dari banyak toko, tidak hanya toko meubelnya sendiri. Kini, beliau merencanakan pengembangan pabrik sofa yang kedua, berlokasi di daerah Gunung Pati. ${ }^{37}$

${ }^{37}$ Wawancara dengan Bapak M. Luthfi, Senin, 20 Juli 2015. 
Bapak Hendro, dalam pengembangan usahanya tak lepas dari etos kerja yang ditunjukkannya dengan bekerja keras, semangat, berpikir positif dan kreatif serta inovatif. Bengkel mobilnya yang berawal dari kecil kini telah berkembang menjadi bengkel besar. Dengan lokasi yang cukup strategis, yaitu di depan Jalan Raya Semarang Boja, hal itu mempermudah beliau dalam promosi. Cakupan layanannya pun juga sangat variatif. Bisa dikatakan bahwa bengkel Satria milik Bapak Hendro ini satu-satunya bengkel terlengkap yang ada di wilayah Ngaliyan. ${ }^{38}$

Bapak Widodo Budi Utomo, meskipun beliau juga punya aktivitas lain selain berbisnis, beliau mampu mengembangkan usahanya menjadi besar. Awalnya toko butiknya hanya menyediakan barang dalam jumlah yang sedikit dan belum variatif. Namun seiring waktu, beliau mampu mengembangkannya dengan berbagai produk. Semangat membangun jaringan memudahkannya dalam penyediaan produk. Beliau tidak perlu mengeluarkan banyak biaya untuk menyediakan barang dagangan di butiknya. Cukup karena kepercayaan, rekanan penyedia barang mau menitipkan barang dagangannya ke butik Bapak Widodo ini. Hal itu adalah bagian dari kreativitas dalam pengembangan usaha. Selain itu, dengan adanya berbagai promo yang seringkali beliau adakan, membuat banyak pelanggan yang datang dan membeli produknya. ${ }^{39}$

Tidak jauh berbeda dengan beberapa pengusaha muslim alumni UIN Walisongo Semarang yang sudah diuraikan di atas, beberapa pengusaha lain juga memiliki variasi dalam pengembangan usahanya. Bapak Fauzan, yang memulai usaha jualan susu murninya dengan sarana seadanya, kini sudah memiliki mobil pick up, menempati dua lokasi yang berbeda, dan telah mampu membayar karyawan. Awalnya beliau berjualan sendiri, tetapi kini sudah dibantu oleh beberapa karyawan. Ini bagian dari kemajuan usaha yang beliau geluti. Dalam penyediaan produk susu murni yang beliau jual, beliau melakukan kreativitas dalam rasa dan tampilan. Hal ini menambah performa usaha jualan susu yang dijalankan. ${ }^{40}$ Tak heran jika usahanya mampu bertahan

\footnotetext{
38 Wawancara dengan Bapak Hendro, Kamis, 27 Agustus 2015.

${ }^{39}$ Wawancara dengan Bapak Widodo Budi Utomo, Senin, 10 Agustus 2015.

40 Wawancara dengan Bapak Fauzan, Sabtu, 22 Agustus 2015.
} 
hingga kini di tengah kondisi ekonomi nasional yang sedang mengalami penurunan daya beli masyarakat karena berbagai tekanan, baik tekanan ekonomi maupun politik.

Ibu Umi Syarifah juga mengalami peningkatan yang cukup signifikan, jika dilihat dari awal mula menjalankan usaha es krimnya. Saat ini peralatan dan sarana yang beliau miliki sudah semakin lengkap, mulai dari box sales, ice pack, freezer, keranjang antar untuk sales dan berbagai alat lainnya. Awalnya hanya satu freezer, dimulai dari hal yang sederhana, dan kini sudah meningkat cukup pesat. Omset yang awalnya hanya mencapai ratusan ribu per hari, kini sudah mendekati angka jutaan rupiah per hari. Rata-rata Ibu Umi Syarifah mampu mengantongi omset per bulan tidak kurang dari Rp. 20 jutaan. ${ }^{41}$

Bapak Helmi Suyanto juga merasakan ada peningkatan usaha meskipun belum signifikan. Beliau menganggap apa yang diperolehnya belum seberapa jika dibandingkan dengan para pengusaha besar. Beliau menganggap dirinya sebagai pengusaha yang biasa-biasa saja. Namun demikian beliau mengakui bahwa semangat bekerja keras akan sebanding dengan hasil yang diperoleh. Perlu ada kreativitas dalam berbisnis agar bisnis yang dijalani bisa tumbuh dan bertahan. Salah satu usaha yang beliau lakukan adalah dengan cara membuat design yang variatif dengan inovasi sesuai permintaan pelanggan. ${ }^{42}$

Apa yang didapatkan oleh para pengusaha muslim alumni UIN Walisongo Semarang adalah sebanding dengan apa yang mereka lakukan. Dengan menerapkan etos kerja yang tinggi, mereka akan mendapatkan hasil yang maksimal. Bapak M. Fahmi misalnya. Usahanya kini telah membuahkan hasil. Peralatan laundry yang beliau miliki jauh lebih lengkap dibanding dengan saat awal mulai menjalankan usaha. Bahkan peralatan usaha untuk percetakan sebagai usaha keduanya, seperti mesin cetak juga sudah beliau miliki. Semua ini tidak lepas dari kerja keras yang dilakukannya selama ini. ${ }^{43}$ Demikian pula dengan Ibu Fauziah Wildan, pengusaha rias pengantin yang tinggal di Perum BPI, Ngaliyan Semarang. Prestasinya sebagai juara 1 lomba

\footnotetext{
${ }^{41}$ Wawancara dengan Ibu Umi Syarifah, Jumat, 24 Juli 2015.

42 Wawancara dengan Bapak Helmi Suyanto, Selasa, 11 Agustus 2015.

${ }^{43}$ Wawancara dengan Bapak M. Fahmi, Sabtu, 15 Agustus 2015.
} 
tata rias tingkat Jawa Tengah dan juara 2 lomba tata rias tingkat nasional adalah salah satu bukti hasil jerih payahnya selama ini. Tidak hanya sampai di situ, usaha rias pengantin yang semula ditekuninya kini sudah berkembang menjadi usaha Wedding Organizer (WO) untuk melengkapi layanan yang berisinergi dengan rias pengantin. Berbagai peralatan usaha pun sudah cukup banyak beliau miliki. ${ }^{4}$

Bapak Solihin juga demikian. Kios fotokopi yang dulunya kecil kini sudah cukup berkembang. Awalnya dengan peralatan biasa yang jumlahnya tidak banyak, kini sudah sangat lengkap dan memadai. Bahkan beliau mengembangkan usaha percetakan sebagai kelanjutan dari usaha fotokopi yang selama ini digeluti. Selain karena posisi tempat usaha yang sangat representatif, yaitu di pinggir jalan raya Ngaliyan Boja dan berdekatan dengan kampus 1 UIN Walisongo Semarang, kerja keras dan tidak mengenal lelah tetap beliau kedepankan dalam pengembangan usaha. Tanpa hal itu mustahil usahanya dapat berkembang seperti sekarang ini. ${ }^{45}$

Tidak jauh berbeda dengan pengusaha yang lainnya, Bapak Ahmad Nasihin yang menegaskan bahwa dalam menjalankan usahanya, selain yang paling utama adalah terus memohon pertolongan dan bantuan Allah swt agar diberi kemudahan dan kesuksesan, bekerja keras dan menjaga semangat adalah dua hal utama yang harus terus dilakukan. Tidak ada usaha yang dijalani dengan santai atau dibiarkan berjalan sekedarnya saja. Bisnis menuntut pelakunya untuk semangat dan bekerja keras. Tanpa itu tidak mungkin usaha bisa maju dan berkembang. Baliau mencontohkan usaha yang dijalaninya. Dari awal usaha dengan modal pinjaman dari calon isterinya dan menjual motor satu-satunya, kini usahanya sudah berkembang cukup baik. Sebagai ganti jerih payahnya, beliau sudah mampu membeli kendaraan, beli rumah dan bahkan tanah serta memiliki usaha tambahan, yaitu usaha rumah kos. Bagi beliau ini sudah menjadi prestasi yang patut disyukuri. Ini adalah balasan dari Allah swt atas doa dan usahanya selama ini. Jatuh bangun

${ }^{44}$ Wawancara dengan Ibu Fauziyah Wildan, Rabu, 26 Agustus 2015.

45 Wawancara dengan Bapak Solihin, Sabtu, 25 Juli 2015. 
memulai usaha kini di bayar dengan berbagai kenikmatan dari hasil usahanya. ${ }^{46}$

Hal serupa juga disampaikan oleh Bapak Sujiantoko dan Bapak Yusuf Isnan serta Ibu Ririn. Secara terpisah mereka mengamini apa yang selama ini diyakini oleh banyak pengusaha, bahwa usaha yang berhasil selalu diawali dengan semangat kerja keras. Dengan kerja keras itu, pelaku usaha akan memperoleh hasil jerih payahnya. Ibu Ririn kini sudah memiliki warung makan dengan beberapa karyawan. Bahkan beliau sudah memiliki peralatan katering sendiri. Semua fasilitas sudah tersedia dan secara hitung-hitungan bisnis, Ibu Ririn sudah mendapatkan pengembalian yang cukup banyak dari hasil usaha yang ditekuninya. ${ }^{47}$ Demikian pula dengan Bapak Sujiantoko dan Bapak Yusuf Isnan. ${ }^{48}$

Masih berkaitan dengan keberhasilan usaha karena etos kerja yang tinggi, Bapak Hasyim Syarbani adalah salah satu pengusaha muslim alumni UIN Walisongo Semarang yang memiliki perhatian akan hal itu. Baginya, mustahil ada pengusaha yang sukses tanpa etos kerja yang tinggi. Semangat, bekerja keras, tidak mudah menyerah, tidak mudah putus asa, kreatif dan inovatif adalah beberapa karakter yang wajib dimiliki oleh pengusaha. Keberhasilan usaha yang saat ini diperoleh oleh Bapak Hasyim tidak lepas dari karakter-karaketr tersebut. Asam garamnya dunia bisnis sudah beliau lalui, sejak muda hingga sekarang. Beliau sangat paham betul bagaimana etos kerja membentuk jiwa pengusaha yang tangguh dan mampu menuntun pelakunya pada keberhasilan usaha. Secara hitung-hitungan materi, beliau menyampaikan bahwa sepertinya tidak menyangka jika saat ini diberi amanah oleh Allah swt rezeki yang sedemikian banyaknya. Sebagian besar rezeki itu diperolehnya dari bisnis yang selama ini digeluti. Tetapi itu semua tidak akan bisa tercapai kalau selama ini beliau bekerja dengan santai, tidak punya rencana untuk ke depannya. Mulai dari usaha percetakan yang sudah membesarkan namanya, beliau kini sudah memiliki toko bangunan, ruko dan banyak properti serta mulai merambah pada usaha poliklinik, apotik, dan jual

\footnotetext{
46 Wawancara dengan Bapak Ahmad Nasihin, Sabtu, 8 Agustus 2015.

${ }^{47}$ Wawancara dengan Ibu Ririn, Jumat, 28 Agustus 2015.

48 Wawancara dengan Bapak Sujiantoko dan Bapak Yusuf Isnan.
} 
beli tanah dan rumah. Semua itu adalah hasil jerih payah dengan etos kerja yang tinggi. ${ }^{49}$

Apa yang dialami oleh para pengusaha muslim alumni UIN Walisongo Semarang sebagaimana paparan di atas juga dialami oleh Bapak Abdul Wahab. Dua kios yang beliau miliki, yaitu kios utama yang ada di Pasar Bulu dan kios kedua yang ada di kampus Universitas Sultan Agung (Unissula) Semarang adalah hasil jerih payahnya selama ini. Baginya tidak akan mungkin seorang pengusaha itu gagal kalau dia mau bergerak dan terus berusaha dengan tanpa mengenal lelah dan menyerah. Beliau membuktikannya sendiri. 50

Uraian di atas memberi gambaran bahwa etos kerja yang baik akan menggiring pelakunya pada kesuksesan usaha. Etos kerja menuntut pelakunya untuk bekerja keras dan mandiri agar tercapai kesuksesan. Islam mengajarkan kerja keras, kemandirian (biyadihi), dan tidak cengeng. Beberapa ayat alQur'an maupun hadis dapat menjadi rujukan tentang semangat kerja keras dan kemandirian ini, seperti; "Amal yang paling baik adalah pekerjaan yang dilakukan dengan cucuran keringatnya sendiri ('amal al-rajuli biyadibi)" (HR. Abu Dawud); "Tangan di atas lebih baik dari tangan di bawah (al-yad alulyā khairun min al-yad al-suflā) (HR. Bukhari dan Muslim). Dengan bahasa yang sangat simbolik ini Nabi saw mendorong umatnya untuk kerja keras supaya memiliki kekayaan, sehingga dapat memberikan sesuatu pada orang lain. Pada QS. al-Nisa [4]:77 Allah mendorong umatnya dengan istilah àtū alzakāh yang menunjukkan pada sebuah kemampuan (untuk memberi). Pada QS. al-Taubah [9]:105, Allah berfirman, "Bekerjalah kamu, maka Allah dan orang-orang yang beriman akan melihat pekerjaan kamu". Bahkan Nabi saw bersabda, "Sesungguhnya bekerja mencari rezeki yang halal itu merupakan kewajiban setelab ibadah fardhu" (HR. Thabrani dan Baihaqi).

Nash di atas secara jelas memberikan isyarat agar manusia bekerja keras dan hidup mandiri. Bekerja keras merupakan esensi dari kewirausahaan. Prinsip kerja keras adalah suatu langkah nyata yang dapat menghasilkan kesuksesan (rezeki), tetapi harus melalui proses yang penuh dengan tantangan

${ }^{49}$ Wawancara dengan Bapak Hasyim Syarbani, Selasa, 8 September 2015.
${ }^{50}$ Wawancara dengan Bapak Abdul Wahab, Jumat, 28 Agustus 2015. 
Etos Kerja Pengusaha Muslim...

(risiko). Dengan kata lain, orang yang berani melewati risiko akan memperoleh peluang rezeki yang besar.

\section{Kesimpulan}

Etos kerja menjadi satu bahasan penting kaitannya dengan pengusaha dan keberhasilan pengusaha dalam menjalankan usahanya. Berdasarkan pada pembahasan mengenai etos kerja pengusaha muslim alumni UIN Walisongo Semarang sebagaimana telah diuraikan sebelumnya, maka dapat disimpulkan bahwa:

1. Pengusaha muslim alumni UIN Walisongo Semarang mempunyai etos kerja yang tinggi sebagai modal dalam menjalankan dan mengembangkan usaha yang digeluti. Semangat kerja mereka tidak hanya didorong oleh motif-motif ekonomi, yaitu supaya bisa memenuhi kebutuhan ekonomi semata, tetapi juga didorong oleh motif religi dan motif sosial. Kualitas etos kerja para pengusaha muslim alumni UIN Walisongo Semarang dalam menjalankan usaha adalah modal utama dalam mengembangkan usaha mereka, selain masing-masing di antara mereka telah mempunyai bekal pengalaman dan keterampilan yang cukup mendalam pada bidang usahanya masing-masing.

2. Etos kerja tinggi yang dimiliki oleh pengusaha muslim alumni UIN Walisongo Semarang telah mampu menghantarkan mereka pada keberhasilan usaha yang digeluti, meskipun dalam kadar yang berbedabeda dengan tingkat keberhasilan yang fariatif. Hal itu ditentukan oleh bidang usaha yang digeluti dan jangka waktu menjalankan usaha. Hal itu juga menunjukkan satu indikasi penting adanya kemampuan yang baik dari para pengusaha tersebut dalam mengelola dan mengembangkan usaha yang selama ini mereka jalani.

Etos kerja sebagai pandangan manusia terhadap kerja yang dilakukan yang dilatarbelakangi oleh nilai-nilai yang diyakininya sangat penting dalam membangun usaha. Oleh karena itu, ada beberapa saran yang dapat disampaikan, sebagai berikut:

1. Membangun etos kerja, selain bisa dilakukan secara sendirian oleh masing-masing pengusaha, akan menjadi lebih baik dan mudah apabila 
ditopang dengan dukungan berbagai pihak. Dukungan itu bisa berupa kerjasama antar pengusaha atau keterlibatan pengusaha dalam forum bersama yang dibentuk oleh para pengusaha muslim alumni UIN Walisongo Semarang.

2. Dalam rangka membangun kerjasama antar pengusaha muslim alumni UIN Walisongo Semarang, maka perlu kiranya dibentuk semacam wadah silaturahmi antar pengusaha alumni UIN Walisongo Semarang. Hal ini akan bermanfaat tidak hanya bagi pengusaha yang bersangkutan, tetapi juga institusi UIN Walisongo Semarang dan para mahasiswa yang ingin menekuni dunia usaha. Melalui forum ini pula akan muncul ide-ide kreatif inovatif yang akan dapat dikembangkan kedepannya.

3. Sudah saatnya bagi UIN Walisongo Semarang sebagai lembaga edukasi tingkat tinggi yang berbasis pada kesatuan ilmu (unity of sciences) untuk memfasilitasi anak didiknya (mahasiswa) untuk belajar berbisnis dengan memanfaatkan potensi yang ada melalui jaringan para pengusaha alumni UIN Walisongo Semarang. Diharapkan melalui mediasi ini akan terlahir penguasa-penguasa muda lulusan UIN Walisongo Semarang yang lebih tangguh dan terdidik, sehingga dapat menjadi salah satu icon UIN Walisongo Semarang yang berhasil mencetak banyak kader pengusaha muslim yang amanah dan tangguh. 
Etos Kerja Pengusaha Muslim...

\section{DAFTAR PUSTAKA}

Abdullah, Taufik, (ed), "Tesis Weber dan Islam di Indonesia dalam Agama", dalam Etos Kerja dan Perkembangan Ekonomi, cet. IV, Jakarta: LP3ES, 1988.

Afzalurrahman, Muhammad sebagai Seorang Pedagang, terjemahan dari Muhammad: Encyclopedia of Seerah, Jakarta: Yayasan Swarna Bhumi, 2000.

Bogdan, Robert and Steven J. Taylor, Introduction to Qualitative Research Methods, New York: 1975.

Burhan, Umar, "Memberdayakan Ekonomi Umat: Suatu Kajian Konsepsional dalam Beberapa Bukti Empiris", Jurnal Lintasan Ekonomi, Malang: Lembaga Penerbit Fakultas Ekonomi Universitas Brawijaya, 1997.

Depdikbud, Kamus Besar Bahasa Indonesia, Jakarta: Depdikbud, 1988.

Fadhely, Mohamad, Meneropong Kebidupan Ekonomi Umat Islam, Peradaban Islam, Kapitalis Budaya Cina di Indonesia. Jakarta: Penerbit Golden Press, 1995.

Ismail, Munawar, "Islam Kapitalisme dan Sosialisme: Studi Komparatif Sistem Ekonomi", Lintasan Ekonomi, Edisi Khusus Januari-April, Malang: Lembaga Penerbit FE Unibraw, 1997.

Mulyadi, Acep, "Islam dan Etos Kerja: Relasi Antara Kualitas Keagamaan dengan Etos Produktivitas Kerja di Daerah Kawasan Industri Kabupaten Bekasi”, Jurnal Turats, Vol. 4 No. 1, Juni 2008

Setyadhi, Jaeroni, "Kewirausahaan Islam dan Bayang-bayang Orientalis Barat”, IHB Jakarta, tanggal 20 September 2005, http//www.fajar.co.id.

Sugiyono, Metode Penelitian Kuantitatif, Kualitatif dan $\mathrm{R}$ \& $\mathrm{D}$, Bandung: Penerbit Alfabeta.

Sukiyanto, "Etos Kerja Salah Satu Faktor Survivalitas Peternak Sapi Perah: Studi Kasus di Desa Sidomulyo Kecamatan Batu Kota Batu Kabupaten Malang", Thesis, Program Pasca Sarjana Universitas Muhammadiyah Malang, 2000.

Surahmad, Winarno, Pengantar Penelitian-penelitian Ilmiah, Dasar Metoda Teknik, Edisi 7, Bandung: Tarsito, 1989.

Tjiptoherijanto, Prijono, "Etos Kerja dan Moral Pembangunan dalam Islam”, makalah tidak diterbitkan, 1988. 
Usman, Sunyoto, Perkembangan dan Pemberdayaan Masyarakat, Yogyakarta: Penerbit Pustaka Pelajar, 1998.

Weber, Max, Etika Protestan dan Semangat Kapitalisme (terj), Penerbit Pustaka Promethea, 2000.

Website resmi UIN Walisongo Semarang (www.walisongo.ac.id dan humaswalisongo.blogspot. com)

Wawancara dengan Bapak M. Luthfi, Senin, 20 Juli 2015.

Wawancara dengan Bapak Helmi Suyanto, Selasa, 11 Agustus 2015.

Wawancara dengan Ibu Umi Syarifah, Jumat, 24 Juli 2015.

Wawancara dengan Bapak M. Fahmi, Sabtu, 15 Agustus 2015.

Wawancara dengan Bapak Solihin, Sabtu, 25 Juli 2015.

Wawancara dengan Bapak Ahmad Nasihin, Sabtu, 8 Agustus 2015.

Wawancara dengan Bapak Sujiantoko, Kamis, 20 Agustus 2015.

Wawancara dengan Bapak Ahmad Yusuf Isnan, Senin, 10 Agustus 2015.

Wawancara dengan Bapak Widodo Budi Utomo, Senin, 10 Agustus 2015.

Wawancara dengan Bapak Hendro, Kamis, 27 Agustus 2015.

Wawancara dengan Ibu Ririn, Jumat, 28 Agustus 2015.

Wawancara dengan Ibu Fauziyah Wildan, Rabu, 26 Agustus 2015.

Wawancara dengan Bapak Fauzan, Sabtu, 22 Agustus 2015.

Wawancara dengan Bapak Hasyim Syarbani, Selasa, 8 September 2015.

Wawancara dengan Bapak Abdul Wahab, Jumat, 28 Agustus 2015. 